\title{
MANAJEMEN PENGELOLAAN ISLAMIC FOODBANK DI INDONESIA (STUDI TEORI DAN KONSEP)
}

\author{
Oleh \\ Alfin Yuli Dianto ${ }^{1}$ \\ M. Wiji Purnomo ${ }^{2}$ \\ Institut Agama Islam Pangeran Diponegoro Nganjuk
}

\begin{abstract}
ABSTRAK
Indonesia memiliki sebuah organisasi nirlaba yang bergerak khusus dalam bidang pangan bernama Foodbank. Salah satu kegiatan Foodbank yaitu memanfaatkan makanan berlebih untuk membantu mengatsi kemiskinan. Islam mengajarkan tentang kedermawanan untuk saling berbagi terhadap sesama terutama membantu mereka yang kekurangan. Bentuk kedermawanan tersebut dapat dilakukan dalam praktik zakat infak sedekah (ZIS) dan dana yang berasal dari ZIS memiliki tujuan untuk dapat mengatasi masalah kemiskinan. Sebagai negara mayoritas muslim, maka sudah sewajarnya jika kita berharap adanya lembaga-lembaga sejenis Foodbank yang mengaplikasikan konsep ZIS, dengan begitu peran Islam dalam membantu mengatasi kemiskinan semakin terwujud. Oleh karena itu, dirasa perlu adanya tawaran konsep baru yaitu Islamic Foodbank yang merupakan pengkolaborasian antara konsep foodbank dengan konsep ZIS dalam satu konsep yang utuh. Didukung dengan belum ditemukannya praktik Foodbank yang berdasarkan konsep Islamic Foodbank. Penelitian ini bertujuan untuk mendeskripsikan bagaimana konsep Islamic Foodbank dan bagaimana rancangan pengaplikasian konsep Islamic Foodbank di Indonesia. Penelitian ini menggunakan pendekatan kualitatif, dengan metode kepustakaan sebagai bagian utamanya. Penelitian ini mengemukakan sebuah hasil bahwasanya konsep Islamic Foodbank merupakan kolaborasi antara konsep Foodbank dengan konsep ZIS yang didukung adanya saling sinergi antara Foodbank dan BAZNAS. Rancangan pengaplikasian konsep ini dimulai dari mendirikan Foodbank yang berbadan hukum resmi, kemudian langkah kegiatan dilakukan secara siklus yang dimulai dari penilaian dan seleksi, pengimplementasian konsep Islamic Foodbank, melaporkan laporan keuangan, tercapainya capaian program, dan evaluasi. Penelitian ini merupakan penelitian pertama tentang konsep Islamic Foodbank di Indonesia yang dilakukan melalui studi literatur.
\end{abstract}


Kata Kunci: Foodbank, Zakat, Infak, Sedekah.

\section{Pendahuluan}

Zakat, infak dan sedekah (ZIS) merupakan bentuk resmi praktik filantropi Islam yang dilakukan bukan atas dasar kewajiban agama saja, akan tetapi juga sebagai wujud dari kepedulian sosial terhadap sesama (Kasdi, 2016). Menurut Razzaq (2014), filantropi Islam dapat diartikan sebagai pemberian sebuah kemurahan hati (charity) yang didasarkan pada pandangan untuk mempromosikan keadilan sosial dan maslahat bagi masyarakat umum. Islam menganjurkan seorang Muslim untuk berfilantropi agar harta kekayaan tidak hanya berputar di antara orang-orang kaya (QS. AlHasyr: 7). Didalam UU No.23 tahun 2011 tentang pengelolaan zakat dijelaskan bahwa zakat adalah harta yang wajib dikeluarkan oleh seorang muslim atau badan usaha untuk diberikan kepada yang berhak menerimanya sesuai dengan syariat Islam. Sedangkan Infak dan sedekah adalah harta yang dikeluarkan oleh seseorang atau badan usaha diluar zakat untuk kemaslahatan umum, akan tetapi sedekah ini juga bisa berbentuk non materi. Di Indonesia, pengelolaan zakat, infak dan sedekah (ZIS) secara resmi di kelola oleh Badan Amil Zakat Nasional (BAZNAS), sebagaimana tertuang dalam UU No. 23 tahun 2011 pasal 5 berbunyi "Bahwa untuk melaksanakan pengelolaan zakat maka pemerintah membentuk Badan Amil Zakat Nasional (BAZNAS)". Pasal 28 berbunyi "BAZ atau LAZ selain menerima zakat juga dapat menerima infak serta sedekah". Apabila zakat dikelola oleh lembaga yang resmi terdaftar di BAZNAS maka zakat yang dibayarakan oleh muzakki dapat mengurangi penghasilan kena pajak, hal ini sesuai dengan isi pasal 23. Jika zakat diberikan kepada delapan ashnaf (Fakir, miskin, amil, muallaf, riqab, gharim, fisabilillah, ibn sabil), maka infak dan sedekah boleh diberikan kepada siapapun (Arsanti, 2007). Adapun berdasarkan Peraturan Badan Amil Zakat Nasional Republik Indonesia Nomor 3 tahun 2018 Tentang Pendistribusian dan pendayagunaan zakat pasal 4 bentuk Pendistribusian zakat dilakukan terhadap bidang pendidikan, 
kesehatan, kemanusiaan dan dakwah dan advokasi. Dana yang bersumber dari ZIS memiliki potensi yang besar, hal ini didukung oleh mayoritas penduduk di Indonesia beragama Islam dan tingkat kepedulian sosial terhadap sesama tengah meningkat. Dana ZIS dapat dijadikan sebagai modal untuk membantu mengatasi masalah kemiskinan. Sedangkan BAZNAS selama ini belum memanfaatkan dana ZIS untuk kegiatan Foodbank (BAZNAS, 2019). Apabila dana ZIS dimanfaatkan dalam bentuk Foodbank, maka dana tersebut akan lebih optimal dan peran ekonomi Islam dalam perekonomian nasional untuk mengentaskan kemiskinan semakin terlihat.

Menurut Mufraini (2006), ada empat bentuk inovasi distribusi zakat yaitu: distribusi bersifat konsumtif tradisional (dibagikan untuk dimanfaatkan secara langsung), bersifat konsumtif kreatif (diberikan dalam bentuk lain dari barangnya semula), bersifat produktif tradisional (diberikan dalam bentuk sesuatu yang produktif), bersifat produktif kreatif (diberikan dalam bentuk permodalan).

Masalah kemiskinan akrab terjadi di negara-negara berkembang, termasuk Indonesia. Kemiskinan merupakan keadaan dimana terjadi ketidakmampuan untuk memenuhi kebutuhan dasar seperti makanan, pakaian, tempat berlindung, pendidikan, dan kesehatan (Wikipedia, 2019). Berdasarkan data Badan Pusat Statistik (2018), angka kemiskinan per Maret 2014-Maret 2018 di Indonesia bersifat fluktuatif. Persentase penurunannya pun tidak mencapai satu persen. Persentase jumlah kemiskinan periode Maret 2014 sebesar 11,25\%, September 2014 sebesar 10,96\%, Maret 2015 sebesar $11,22 \%$, September 2015 sebesar 11,13\%, Maret 2016 sebesar 10,86\%, September 2016 sebesar 10,70\%, Maret 2017 sebesar 10,64\%, September 2017 sebesar 10,12\% dan pada periode Maret 2018 sebesar 9,82\%. Itu artinya masalah kemiskinan adalah masalah yang mendesak yang terus membutuhkan tawaran solusi untuk mengatasinya. Salah satu tawaran solusi tersebut bisa melalui adanya Foodbank.

Foodbank adalah organisasi sosial nirlaba yang memiliki jaringan secara internasional bernama Global Foodbanking Network (GFN), berfungsi untuk menghimpun dan menyalurkan makanan 
berlebih. Dipercaya sebagai solusi integral dan layak dalam memberdayakan dunia untuk mengatasi kelaparan, mengurangi foodwaste, dan mengatasi masalah kemiskinan (Foodbanking, 2018).

Foodbank merupakan organisasi amal yang berfungsi sebagai tempat pengumpulan, penyimpanan dan distribusi surplus makanan yang dibagikan secara gratis kepada organisasi amal lain maupun didistribusikan secara langsung kepada masyarakat yang membutuhkannya (Hasan, 2012). Menurut Riches (2002), Foodbank merupakan agen sosial yang memiliki tujuan mengumpulkan, menyimpan, dan mendistribusikan kelebihan makanan secara gratis kepada orang-orang yang mengalami kelaparan. Foodbank of Indonesia (FOI) adalah Foodbank pertama di Indonesia, berdiri pada tahun 2015 kemudian disusul oleh FoodCycle Indonesia yang berdiri pada tahun 2017 dan Garda Pangan Surabaya yang resmi berdiri pada tahun 2018 (Wibowo, 2018). Setiap organisasi maupun lembaga membutuhkan kestabilan financial dan sumber penghasilan yang sustainable untuk terus bertahan dalam menjalankan kegiatannya, termasuk Foodbank (Official, 2018). Dari ketiga Foodbank ini belum ada yang melakukan pengelolaan ZIS secara resmi dalam bentuk LAZ dan belum menerapkan konsep ZIS sepenuhnya. Potensi dana ZIS yang besar berpotensi untuk menyokong berjalannya kegiatan Foodbank.

Secara umum, sumber makanan yang dibagikan berasal dari donasi baik personal maupun perusahaan dan menjalin mitra kerja (Official, 2018). Foodbank berfokus pada penyelamatan makanan berlebih untuk dimanfaatkan secara efektif dan dibagikan secara bermartabat. Foodbank beroperasi tanpa dana keuangan dari pihak pemerintah, namun mengandalkan layanan sukarela (Gardapangan, 2018). Makanan yang dapat disumbangkan yaitu semua jenis makanan yang tidak kedaluwarsa, higienis, dan layak di konsumsi.

Proses pengelolaan makanan juga memiliki Standart Operasional Prosedur (SOP) yang jelas (Gardapangan, 2018). Sasaran penerima bantuan berasal dari laporan relawan, masyarakat sekitar, disurvei lebih lanjut dan di data secara rapi. Pemberian bantuan tidak diberikan setiap hari akan tetapi pada hari-hari tertentu dalam satu 
minggu. Diimbangi pula pemberian edukasi dan sosialisasi agar masyarakat lebih terampil dalam bidang pangan (Foodbankindonesia, 2018).

Adapun prosedur pendirian Foodbank baru berdasarkan sebuah panduan yang dibuat oleh The Global Foodbanking Network tentang analisis kelayakan memulai sistem bank pangan (Foodbanking, 2018), intinya ada lima fase untuk melakukan pendirian sistem perbankan makanan, yaitu :

a. Fase Penilaian

Fase ini meliputi:

1) Melakukan tinjauan serius terhadap isu-isu lingkungan yang terkait dengan pendirian dan pengoperasian sistem bank makanan yang sedang berlangsung.

2) Menganalisis kebutuhan-kebutuhan, meliputi: siapa yang mengalami kelaparan, dimana mereka berada, apa penyebab kelaparan, dan lain-lain.

3) Melakukan studi mendalam tentang semua program pemberian makanan yang ada, apakah dioperasikan oleh pemerintah, sektor swasta atau masyarakat sipil.

4) Mengevaluasi hasil analisis kebutuhan terhadap analisis layanan yang sudah ada saat in untuk mengetahui apakah masih ada kesenjangan dalam layanan dan sekaligus untuk membantu menentukan prioritas program.

5) Melakukan penilaian berbasis sumber daya dalam hal makanan, dana, dan sukarelawan.

6) Menganalisis lingkungan hukum dan peraturan di mana bank makanan akan beroperasi yang mencakup tinjauan terhadap undang-undang dan peraturan yang ada terkait dengan masalah keamanan pangan, masalah transportasi, perlindungan kewajiban bagi perusahaan yang memberikan sumbangan produk dengan itikad baik, pengurangan pajak dan lain-lain. Hal ini sangat penting dilakukan karena bank makanan harus terstruktur, diatur, dan dikelola dengan tepat untuk mempromosikan transparansi penuh dan kepercayaan. 
7) Menetapkan anggaran dan mengidentifikasi satu atau beberapa sponsor utama untuk membiayai tahap awal ini.

8) Mengambil keputusan untuk bergerak maju dengan membangun sistem bank makanan.

b. Fase Perencanaan

Membuat Rencana Bisnis dan Rencana Pengembangan Sumber Daya. Rencana Bisnis akan menentukan struktur, tata kelola, manajemen, operasi, dan administrasi sistem bank makanan. Ini akan mencakup asumsi dan keputusan yang diperlukan mengenai persyaratan kepegawaian, persyaratan fasilitas dan armada, prosedur operasi, tuntutan logistik, prosedur pemberian layanan, rencana komunikasi dan hubungan media, serta rencana penjangkauan masyarakat dan pengembangan kemitraan. Mencakup rencana penggalangan dana yang sedang berlangsung untuk memastikan keberlanjutan dan pertumbuhan yang sesuai dan perluasan layanan.

Tahap paling penting, dalam pembuatan perencanaan ini harus menetapkan tujuan dan sasaran ruang lingkup dan skala layanan bank makanan:

1) Apakah akan melayani orang yang kelaparan secara langsung atau melalui LSM lain atau keduanya?

2) Apakah ia akan berusaha menyediakan $100 \%$ kebutuhan pangan lembaga penerima atau sejumlah yang lebih kecil?

3) Apakah akan mencoba menjangkau semua orang yang kelaparan di Negara atau komunitas atau akankah menargetkan segmen tertentu dari populasi yang membutuhkan?

4) Apakah ia hanya menyediakan makanan yang tidak mudah rusak, kemasan atau akankah juga menyediakan makanan beku dan produk segar?

5) Apakah ia hanya menyediakan makanan atau akan juga menangani produk-produk bahan makanan non-pangan (persediaan pembersih, popok, barang-barang perawatan pribadi, barang-barang layanan makanan, dan lain-lain)?

6) Apakah hanya akan menangani produk makanan dan bahan makanan atau akan juga menangani barang-barang lain seperti pakaian, furnitur, barang-barang rumah tangga, dan lain-lain? 
7) Bagaimana ia akan menentukan aktivitas distribusi target dan mengukurnya terhadap target tersebut?

c. Fase Kapitalisasi

Setelah semua perencanaan selesai dan bank makanan siap untuk beralih dari konsep ke kenyataan, proyek pindah ke fase kapitalisasi. Dalam fase ini, perwakilan yang tepat dari proyek menyiapkan sumber pendanaan yang diidentifikasi untuk memanfaatkan permulaan sistem bank makanan.

d. Fase Implementasi

Setelah membuat perencanaan yang matang dan mengamankan kapitalisasi yang diperlukan, sekarang saatnya untuk meluncurkan operasi.

e. Fase Penyesuaian

Rencana harus dibuat untuk melakukan penilaian operasi penuh di beberapa titik sepanjang tahun pertama. Paling tidak, ini harus menjadi peringatan 3 bulan, 6 bulan, dan 1 tahun dari peluncuran operasi. Penilaian formal ini akan memastikan bahwa masalah-masalah yang mungkin terjadi akan ditangani dengan tepat secara komprehensif, dengan kata lain resolusi dari satu masalah tidak menciptakan masalah baru terkait masalah lain. Setiap masalah harus ditangani dengan cara yang memastikan bahwa keseluruhan operasi terus berjalan dengan lancar dan efektif.

Pada dasarnya salah tujuan dari kegiatan Foodbank dan pengelolaan dana ZIS adalah sama, yaitu membantu mengatasi masalah kemiskinan. Sebagai negara yang mayoritas muslim, maka sudah sewajarnya jika kita berharap adanya lembaga-lembaga sejenis Foodbank yang mengaplikasikan konsep ZIS, dengan begitu peran Islam dalam membantu mengatasi kemiskinan semakin terwujud. Oleh karena itu, dirasa perlu adanya tawaran konsep baru yaitu Islamic Foodbank yang merupakan pengkolaborasian antara konsep foodbank dengan konsep ZIS dalam satu konsep yang utuh. Didukung dengan belum ditemukannya praktik Foodbank yang berdasarkan konsep Islamic Foodbank. Penelitian ini bertujuan untuk mendeskripsikan bagaimana konsep Islamic Foodbank dan bagaimana rancangan pengaplikasian konsep Islamic Foodbank di Indonesia. 
Metode penelitian yang digunakan adalah metode library research. Subjek penelitian meliputi Lembaga Badan Amil Zakat Nasional (BAZNAS), tiga Foodbank yang ada di Indonesia (Foodbank Of Indonesia, FoodCycle Indonesia, dan Garda Pangan Surabaya), sedangkan objek penelitian adalah konsep pengelolaan Foodbank dan ZIS. Teknik pengumpulan data menggunakan taknik triangulasi. Selanjutnya data hasil peneletian dianalisis dengan menggunakan metode analisis deskriptif kualitatif.

\section{Pembahasan}

\section{Konsep Islamic Foodbank di Indonesia}

Konsep Islamic Foodbank dirancang berdasarkan data yang telah di paparkan dalam pendahuluan. Konsep ini sebenarnya tidak jauh berbeda dengan konsep Foodbank, Konsep Islamic Foodbank merupakan kolaborasi antara konsep Foodbank dengan konsep ZIS yang didukung adanya saling sinergi antara Foodbank dan BAZNAS, selanjutnya akan berdiri Islamic Foodbank di Indonesia. Bentuk sinergitas tersebut direalisasikan dalam bentuk Foodbank melakukan pengelolaan ZIS secara legal (terdaftar sebagai LAZ di BAZNAS) dan BAZNAS mendirikan Foodbank sebagai bentuk pengembangan pengelolaan dana ZIS agar lebih optimal. Konsep Islamic Foodbank ini dirancang sebagai bentuk pengembangan konsep yang sudah ada dan dengan tujuan agar dapat diaplikasikan sebagai salah satu cara untuk meningkatkan eksistensi BAZNAS dan Foodbank serta sebagai langkah membumikan syiar ekonomi Islam di Indonesia.

Sebagai bentuk dari praktik filantropi, praktik Foodbank dan ZIS, keduanya memiliki kesamaan tujuan yaitu untuk membantu mengatasi masalah kemiskinan. Berdasarkan pemaparan yang disebutkan sebelumnya, sumber dana yang berasal dari ZIS memiliki potensi besar, sedangkan Foodbank membutuhkan input tetap yang sifatnya sustainable untuk terus bertahan dalam menjalankan kegiatannya. Dana ZIS tersebut akan lebih optimal apabila dimanfaatkan oleh Foodbank. Sehingga, kelebihan dan kekurangan yang dimiliki keduanya digunakan untuk saling melengkapi dan 
menyempurnakan. Skema konsep Islamic Foodbank di Indonesia akan di tunjukkan pada gambar 1 .

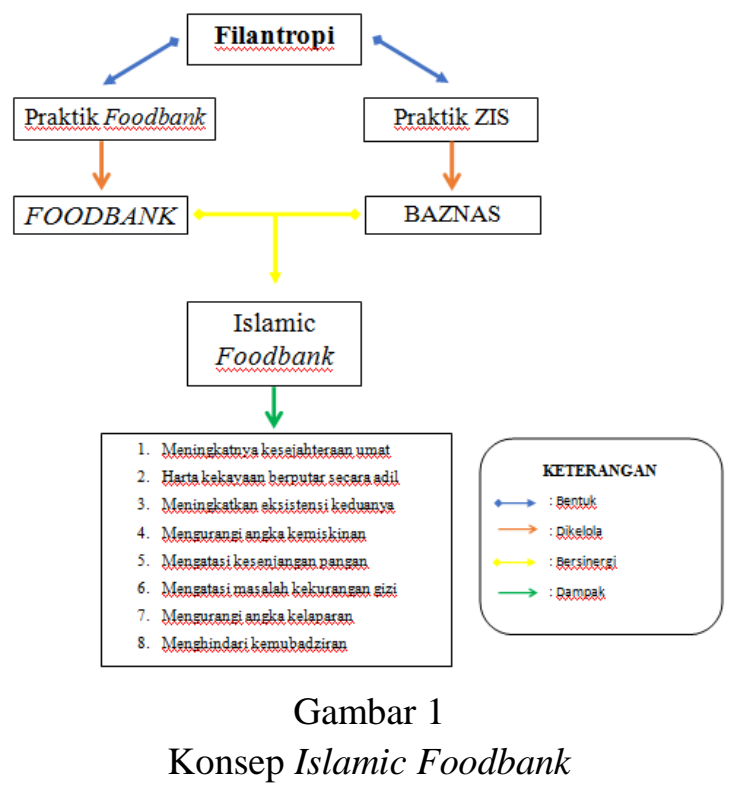

Sumber: Data diolah dari berbagai macam sumber

Praktik Foodbank dan praktik zakat, infak, serta sedekah (ZIS) dalam skema tersebut merupakan bentuk praktik filantropi. Praktik kegiatan foodbank yang merupakan bagian dari sebuah pergerakan sosial (social movement) tersebut dikelola oleh Foodbank yaitu sebuah sebuah organisasi sosial yang bergerak khusus dalam bidang pangan dan memanfaatkan makanan berlebih dengan arah tujuan yg jelas. Sedangkan praktik ZIS dikelola oleh BAZNAS selaku pihak yang dibentuk pemerintah untuk menerima zakat dan juga dapat menerima infak serta sedekah. Dalam pelaksanaan pengumpulan, pendistribusian, dan pendayagunaan ZIS, BAZNAS dibantu oleh Lembaga Amil Zakat (LAZ) yang merupakan lembaga pengelola zakat yang didirikan oleh swasta. Agar Foodbank dapat mengelola ZIS secara legal dan dana ZIS dapat dimanfaatkan secara lebih optimal dengan cara mengembangkan pengelolaan dana ZIS melalui pendirian Foodbank, maka antara Foodbank dan BAZNAS saling 
bersinergi. Berawal dari alasan tersebut akhirnya dibuatlah sebuah rancangan konsep Islamic Foodbank agar proses sinergi dapat direalisasikan untuk mewujudkan Islamic Foodbank di Indonesia. Setelah adanya sinergitas, keberadaan Islamic Foodbank akan memberikan dampak berupa meningkatnya kesejahteraan umat, harta kekayaan berputar secara adil, meningkatkan eksistensi keduanya, mengurangi angka kemiskinan, mengatasi kesenjangan pangan, mengurangi masalah kekurangan gizi, mengurangi angka kelaparan, dan dapat menghindari kemubadziran.

\section{Rancangan Pengaplikasian Konsep Islamic Foodbank di Indonesia}

Konsep Islamic Foodbank dirancang untuk dapat diaplikasikan secara luas. Sehingga, BAZNAS selaku pihak yang mengelola ZIS secara resmi juga dapat mengaplikasikan konsep ini. Berikut akan dipaparkan rancangan pengaplikasian konsep Islamic Foodbank di BAZNAS.

Adapun tahapan langkah pengaplikasian konsep Islamic Foodbank di BAZNAS berdasarkan pada teori yang telah disebutkan sebelumnya. Berikut tahapan langkah pengaplikasiannya:

a. Mendirikan Foodbank.

b. Melakukan penilaian dan seleksi untuk menentukan darimana sumber pemasukan, apa saja bentuk pemasukan, siapa saja sasaran penerima, dan mengikuti prosedur pendayagunaan.

c. Mengimplementasikan konsep Islamic Foodbank.

d. Melaporkan laporan keuangan secara berkala kepada menteri sesuai dengan peraturan Undang undang No. 23 tahun 2011 tentang pengelolaan zakat pasal 29 ayat 4 .

e. Tercapainya capaian program.

f. Melakukan evaluasi.

g. Langkah kedua sampai keenam dilakukan secara siklus setelah Foodbank telah berdiri.

Lengkapnya, detail kegiatan dalam setiap tahapan rancangan pengaplikasian konsep Islamic Foodbank di BAZNAS adalah paling 
tidak ada 6 tahapan langkah yang perlu diupayakan dalam mewujudkan implementasi konsep Islamic Foodbank di Indonesia.

Tabel 1

Detail kegiatan dalam setiap tahapan rancangan

pengaplikasian konsep

Islamic Foodbank di BAZNAS

\begin{tabular}{|c|c|c|}
\hline No & $\begin{array}{l}\text { Tahapan } \\
\text { Langkah } \\
\text { Kegiatan }\end{array}$ & Detail Kegiatan \\
\hline 1. & Pendirian & 1.1 Mendirikan Foodbank. \\
\hline 2. & $\begin{array}{r}\text { Penilaian dan } \\
\text { Seleksi }\end{array}$ & $\begin{array}{l}\text { 1.1 Sumber pemasukan: dana dari } \\
\text { muzakki dan donator umum. } \\
\text { 1.2 Bentuk pemasukan: dana ZIS, dana } \\
\text { sosial lainnya, makanan dan barang. } \\
\text { 1.3 Sasaran penerima: mengutamakan } \\
\text { fakir dan miskin, } 7 \text { ashnaf yang lain } \\
\text { dengan memperhatikan: } \\
\text { 1.3.1 Sesuai syariat Islam. } \\
\text { 1.3.2 Berdasar skala prioritas. } \\
\text { 1.3.3 Memperhatikan } \\
\text { pemerataan. } \\
\text { 1.3.4 Memperhatikan } \\
\text { keadilan. } \\
\text { 1.3.5 Memperhatikan } \\
\text { kewilayahan. } \\
\text { 1.3.6 Menyesuaikan banyaknya } \\
\text { dana yang terkumpul. } \\
\text { 1.3.7 Pembagian sesuai kondisi } \\
\text { mustahiq dan tidak harus } \\
\text { sama rata. } \\
\text { 1.4 Prosedur pendayagunaan : } \\
\text { 1.4.1 Melakukan studi kelayakan. } \\
\text { 1.4.2 Menetapkan usaha produktif. }\end{array}$ \\
\hline
\end{tabular}




\begin{tabular}{|c|c|c|}
\hline & & $\begin{array}{l}\text { 1.4.3 Melakukan bimbingan dan } \\
\text { penyuluhan. } \\
\text { 1.5 Melakukan evaluasi. }\end{array}$ \\
\hline 3. & Implementasi & $\begin{array}{l}\text { 3.1 Mengaplikasikan Konsep Islamic } \\
\text { Foodbank yaitu BAZNAS melakukan } \\
\text { serangkaian kegiatan-kegiatan } \\
\text { Foodbank. } \\
\text { 3.2 Bentuk pendistribusian: } \\
\text { 3.2.1 Bidang pendidikan: beasiswa } \\
\text { sekolah kuliner untuk anak- } \\
\text { anak dari golongan fakir } \\
\text { miskin, anak yatim, dan anak- } \\
\text { anakjalanan. } \\
\text { 3.2.2 } \text { Bidang kesehatan: kampanye } \\
\text { kreatif terkait kesadaran } \\
\text { memperhatikan gizi makanan } \\
\text { di berbagai kegiatan dan } \\
\text { forum. kemanusiaan: } \\
\text { 3.2.3 Bidang pang } \\
\text { memberikan pertolongan yang } \\
\text { dibutuhkan dan bantuan } \\
\text { langsung tunai baik berupa } \\
\text { makanan maupun barang yang } \\
\text { dibagikan kepada para korban } \\
\text { bencana alam. } \\
\text { 3.2.4 Bidang dakwah: memberikan } \\
\text { edukasi terkait isu sampah } \\
\text { makanan kepada masyarakat. } \\
\text { 3.2.5 Bersifat konsumtif tradisional : } \\
\text { memberikan bantuan makanan } \\
\text { baik makanan siap saji, kue, } \\
\text { buah, dan susu pada hari-hari } \\
\text { tertentu misalnya senin dan } \\
\text { kamis secara bergantian kepada }\end{array}$ \\
\hline
\end{tabular}




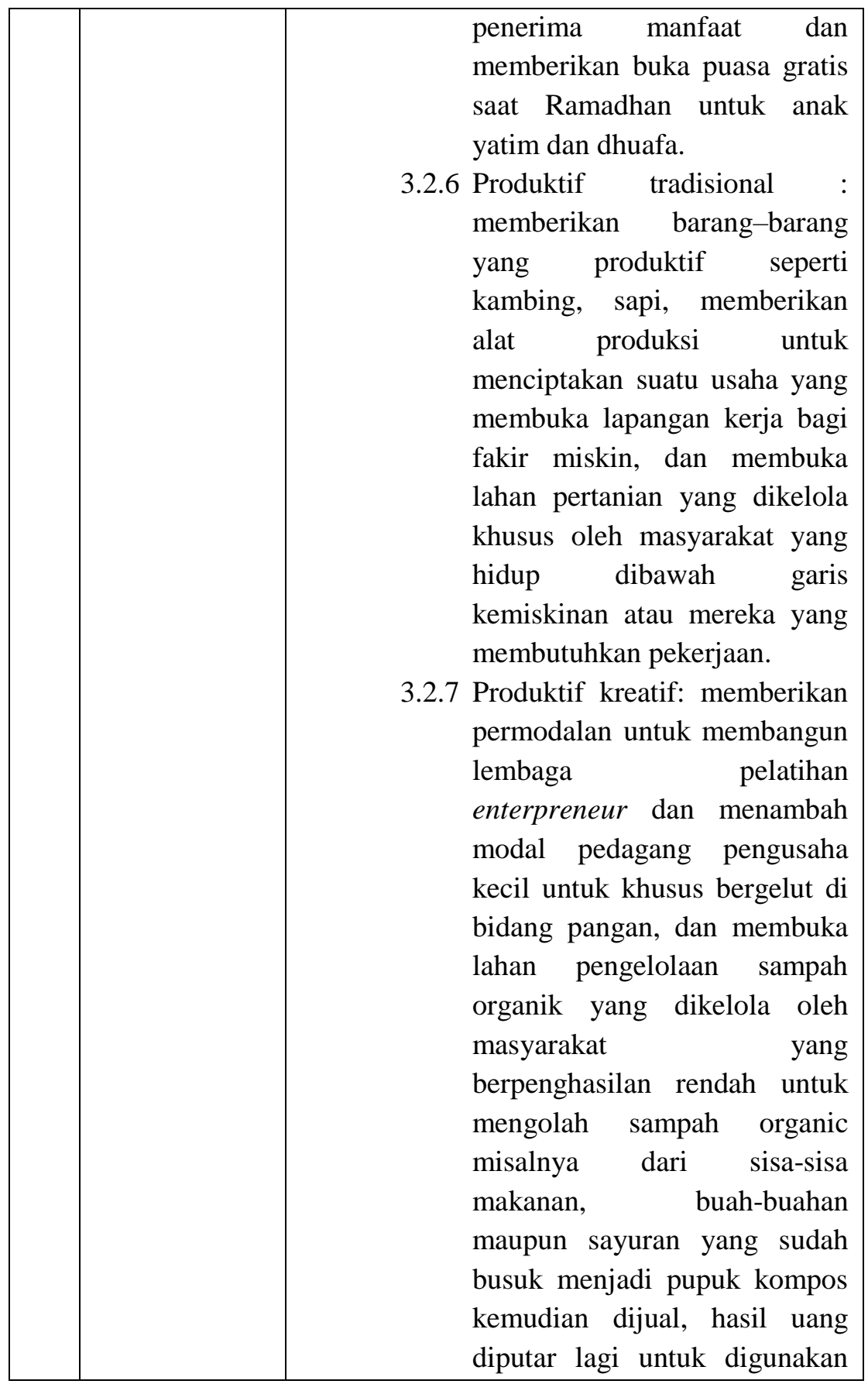




\begin{tabular}{|c|c|c|}
\hline & & dalam memberikan beasiswa. \\
\hline 4. & Pelaporan & $\begin{array}{l}\text { Melaporkan laporan keuangan secara } \\
\text { berkala kepada menteri sesuai dengan } \\
\text { peraturan Undang undang No. } 23 \text { tahun } \\
2011 \text { tentang pengelolaan zakat pasal } 29 \\
\text { ayat } 4 .\end{array}$ \\
\hline 5. & $\begin{array}{l}\text { Capaian } \\
\text { Program }\end{array}$ & $\begin{array}{ll}\text { 5.1 } & \text { Dana ZIS dapat dimanfaatkan secara } \\
& \text { lebih optimal. } \\
5.2 & \text { Meningkatnya kesejahteraan umat. } \\
5.3 & \text { Harta kekayaan berputar secara adil. } \\
5.4 & \text { Mengurangi nominal penghasilan kena } \\
& \text { pajak muzakki. } \\
5.5 & \text { Bertambahnya jumlah Foodbank di } \\
& \text { Indonesia. } \\
5.6 & \text { Berkurangnya angka kemiskinan. } \\
5.7 & \text { Teratasinya masalah kesenjangan } \\
& \text { pangan. } \\
\text { 5.8 } & \text { Teratasinya masalah kekurangan gizi. } \\
\text { 5.9 } & \text { Turunnya angka kelaparan. } \\
5.10 & \text { Terhindar dari pemubadziran } \\
& \text { makanan. }\end{array}$ \\
\hline 6. & Evaluasi & $\begin{array}{r}\text { Melakukan evaluasi program yang telah } \\
\text { dilaksanakan. }\end{array}$ \\
\hline
\end{tabular}

Sumber: Data diolah dari berbagai macam sumber

Untuk lebih mudahnya berikut gambaran skema tahapan langkah pengaplikasian konsep Islamic Foodbank di BAZNAS. 


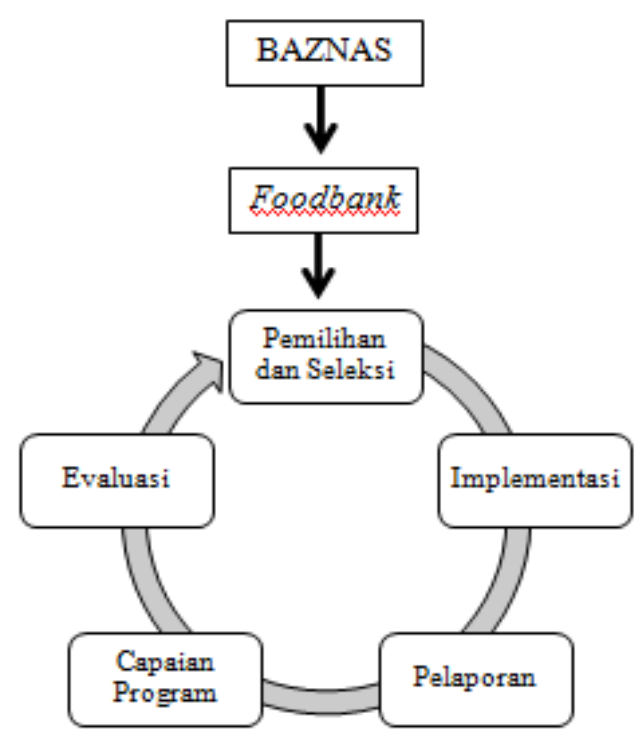

Gambar 2

Skema tahapan langkah pengaplikasian konsep

Islamic Foodbank

\section{di BAZNAS}

Sumber: Data diolah dari berbagai macam sumber

\section{Penutup}

Konsep Islamic Foodbank ini tidak jauh berbeda dengan konsep foodbank yang sudah ada. Konsep Islamic Foodbank merupakan kolaborasi antara konsep foodbank dengan konsep zakat, infak, dan sedekah (ZIS) yang didukung dengan adanya saling sinergi antara Foodbank dan BAZNAS selaku pihak pengelola kegiatan foodbank dan ZIS. Konsep baru Islamic Foodbank ini dirancang sebagai bentuk pengembangan konsep yang sudah ada dengan maksud agar dapat diaplikasikan sebagai salah satu cara untuk meningkatkan eksistensi Foodbank dan BAZNAS serta sebagai langkah membumikan syiar ekonomi Islam di Indonesia. 
Konsep Islamic Foodbank dirancang untuk dapat diaplikasikan secara luas. Sehingga, BAZNAS selaku pihak yang mengelola ZIS secara resmi juga dapat mengaplikasikan konsep ini. Rancangan pengaplikasian konsep ini dimulai dari mendirikan Foodbank yang berbadan hukum resmi, kemudian langkah kegiatan dilakukan secara siklus yang dimulai dari penilaian dan seleksi, pengimplementasian konsep Islamic Foodbank, melaporkan laporan keuangan, tercapainya capaian program, dan evaluasi.

\section{Daftar Pustaka}

[1]. Kasdi, A. 2016. Filantropi Islam Untuk Pemberdayaan Ekonomi Umat. Jurnal Iqtishadia, 9 (2): 230.

[2]. Razzaq, A. 2014. Pengembangan Model Pembangunan Ummat Melalui Lembaga FilantropiIslam Sebagai Bentuk Dakwah bil Hal. Intizar, 20 (1): 165.

[3]. Arsanti, B. 2007. Pengelolaan Zakat Pada Lembaga Amil Zakat Infaq Shodaqoh (LAZIS)Muhammadiyah Kabupaten Gunung Kidul. Skripsi tidak diterbitkan. Yogyakarta: UIN Sunan Kalijaga.

[4]. Mufraini, MA. 2006. Akutansi dan Manajemen Zakat Cet.1. Jakarta : Kencana.

[5]. https://id.wikipedia.org/wiki/kemiskinan (diakses pada 4 Juli 2019 pukul 21.42 WIB).

[6]. https://www.bps.go.id/pressrelease/2018/07/16/1438/persenta se-penduduk-miskin-maret-2018-turun-menjadi-9-82persen.html(diakses pada 28 Feb 2019, pukul 23.34 WIB).

[7]. https://www.Foodbanking.org/what-we-do/, (diakses pada 7 Agustus 2019 pukul 19.35 WIB)

[8]. Hasan, N.B. 2012. Potensi Pelaksanaan Bank Makanan di Malaysia

Sebagai Satu Bentuk Jaminan Sekuriti Makanan Bagi Golongan Miskin. Disertasi. Universitas Malaya: Kuala Lumpur.

[9]. Riches, G. 2002. Food Banks And Food Security: Welfare Reform, Human Rights and 
Social Policy. Lessons From Canada?. Social Policy \& Administration, 36 (6): 650.

[10]. https://womantalk.com/food/articles/ini-3-food-bank-yangada-di- indonesia-DrJ7m, (diakses pada 6 Juli 2019, pukul 16.34 WIB).

[11]. https://www.youtube.com/watch?v=sZYT68sd76k\&t=89s, (diakses pada 17 Agustus 2019, pukul 10.00 WIB).

[12]. https://gardapangan.org/tentang-kami/, (diakses pada 19 Juli 2019, pukul 15.05 WIB).

[13]. https://gardapangan.org/mitra/, (diakses pada 18 Mei 2019 pukul 10.16WIB).

[14]. http://foodbankindonesia.org/program/, (diakses pada $18 \mathrm{Mei}$ 2019, pukul 10.18 WIB).

[15]. Undang-Undang No.23 Tahun 2011 tentang Pengelolaan Zakat.

[16]. Peraturan Badan Amil Zakat Nasional Republik Indonesia Nomor 3 Tahun 2019

[17]. Departemen Agama RI. 2005. Al Qur'an dan Terjemah. PT Syaamil Cipta Media.

[18]. Hasil wawancara dengan pihak BAZNAS Indonesia, wawancara melalui pesan instagram, pada 12 Agustus 2019

[19]. Hasil wawancara dengan ibu Wida Septarina founder FOI, wawancara melalui pesan whatsapp, pada 5 Agustus 2019

[20]. Hasil wawancara dengan pihak FoodCycle, wawancara melalui pesan instagram, pada 2 Agustus 2019

[21]. Hasil wawancara dengan ibu Eva Bachtiar founder Garda Pangan, wawancara melalui pesan whatsapp, pada 19 Juli 2019

[22]. Global Food Banking Network, https://www.Foodbanking.org/ , (diakses pada 18 Agustus 2019 pukul 17.10 WIB) 
Jurnal Dinamika Ekonomi Syariah http://ejurnal.iaipd-nganjuk.ac.id/index.php/es p-ISSN: 2654-3567 